УДК 616.366-002-036.11-06:616.366/.367-003.7-036.11-079.2

DOI 10.11603/2414-4533.2018.2.9195

(СО. М. ТЕРЛЕЦЬКИЙ, В. І. КОЛОМІЙЦЕВ

Львівський національний медичний університет імені Данила Галицького

\title{
Проблема діагностики малосимптомного холедохолітіазу в пацієнтів із гострим калькульозним холециститом
}

\begin{abstract}
Мета роботи: покращити результати діагностики малосимптомного холедохолітіазу.
Матеріали і методи. Проведено аналіз діагностики та лікування 167 пацієнтів з гострим калькульозним холециститом та підозрою на холедохолітіаз у період із 2007 до 2016 р.

Результати досліджень та їх обговорення. Пацієнти з гострим калькульозним холециститом та малосимптомним холедохолітіазом найчастіше скаржилися на біль у правій підреберній та епігастральній ділянках (95,8 \%), підвищення температури тіла (47,9 \%) та загальну слабість $(87,4$ \%) і лише у 4 (2,3 \%) пацієнтів спостерігали тріаду Шарко (жовтяниця, лихоманка, дрощі). При аналізі біохімічних показників крові спостерігали підвищення рівня білірубіну лише у 38 (22,7 \%) пацієнтів, а лужної фосфатази у 131 (78,4 \%) та гамаглютамілтранспептидази у 139 (83,2 \%) пацієнтів. За результатами УзД підозра на холедохолітіаз виникла у 68,8 \% пацієнтів; діаметр загальної жовчної протоки склав в середньому $(9,0 \pm 0,21)$ мм. Не виявлено УзД-ознак гіпертензії або іншої біліарної протокової патології у $52(31,1 \%)$ пацієнтів. Серед 41 пацієнта за допомогою МРХПГ діагностовано холедохолітіаз у 30 (73,2 \%) хворих. Під час ЕРХПГ виявлено конкременти у 97,8 \% пацієнтів. Ускладнення після проведення лікувальної ЕРХПГ виникли у 5 (3,6 \%) пацієнтів.
\end{abstract}

Ключові слова: малосимптомний холедохолітіаз; ультрасонографія; ендоскопічна ретроградна холангіопанкреатикографія; магнітнорезонансна холангіопанкреатикографія.

Постановка проблеми i аналіз останніх досліджень та публікацій. На сьогодні більшість наукових публікацій описує проблеми виявлення патологічних змін позапечінкових жовчних проток в основному в пацієнтів із хронічним калькульозним холециститом, коли лікар не відчуває дефіциту часу, вибираючи необхідні обстеження із всього арсеналу доступних методів обстеження $[2,8]$. Публікацій, присвячених виявленню малосимптомних змін жовчовивідних шляхів при гострому калькульозному холециститі, практично немає. В літературі описуються спостереження, в яких вказано, що жовтяниця при гострому холециститі, а частіше лише біохімічні зміни, які вказують на холестаз без клінічних проявів, можуть бути наслідком періхоледохеального лімфаденіту, інфільтрату гепатодуоденальної зв'язки і супутнього гепатиту, які виникають при деструктивному холециститі в $25,8 \%$ випадків [1, 3]. Таке трактування призводить до того, що клініко-лабораторні зміни часто ігнорують і пацієнтам не проводять повноцінного передопераційного обстеження жовчовивідних шляхів. Хірурги, як правило, виконують лапароскопічну холецистектомію без ревізії проток, і наявність конкрементів у протоках виявляють у ранньому післяопераційному періоді, що пізніше класифікується як постхолецистектомічний синдром $[1,5]$.

Основними симптомами холедохолітіазу є біль в епігастральній ділянці, жовтяниця, диспептичні прояви, лихоманка. Симптомний холедохолітіаз можна діагностувати за допомогою комплексної оцінки специфічних симптомів, найважливішим серед яких є механічна жовтяниця. Малосимптомна форма, що зустрічається у 5-30 \% хворих на гострий калькульозний холецистит [3], часто характеризується лише загальними неспецифічними ознаками, що за наявності гострого холециститу не мають діагностичної цінності і хірурги не звертають на них уваги $[2,5,7,9]$.

Невирішеність діагностично-лікувальної тактики у хворих з малосимптомним холедохолітіазом при гострому калькульозному холециститі спонукали нас для проведення дослідження в даному напрямку.

Матеріали і методи. Проведено ретроспективний аналіз результатів діагностики та хірургічного лікування 167 пацієнтів з гострим калькульозним холециститом та підозрою на холедохолітіаз, у період з 2007 до 2016 р., що перебували на лікуванні в клініці хірургії № 1 Львівського національного медичного університету. Критеріями відбору були пацієнти, які не мали виражених клінічних або лабораторно-апаратних проявів холедохолітіазу.

Відповідно до протоколів і стандартів надання медичної допомоги хірургічним хворим із гострим калькульозним холециститом, ускладненим холедохолітіазом, крім клінічного обстеження, проводили загальний і біохімічний аналізи крові, загальний аналіз сечі, визначали стан системи згортання крові. 3 апаратних та інструментальних методів діагностики застосовували транс- 
абдомінальне ультразвукове обстеження органів черевної порожнини (УЗД), езофагогастродуоденоскопію (ЕГДС), ендоскопічну ретроградну холангіопанкреатикографію (ЕРХПГ), комп’ютерну томографію (KT), магнітно-резонансну холангіопанкреатикографію (МРХПГ). Статистичний аналіз проводили за допомогою програмного забезпечення Microsoft Excel 2010.

Результати досліджень та їх обговорення. Всі пацієнти ургентно госпіталізовані через 2 години - 17 днів від початку захворювання $(\mathrm{Me}=$ середній час - (64 \pm 37$)$ год). Чоловіків було 43 (25,7 \%), жінок -124 (74,2 \%). Середній вік хворих становив $(59 \pm 15,4)$ року і коливався від 20 до 87 років. Із 167 пацієнтів лапароскопічним методом прооперовано 131 (78,8 \%) хворого, відкритим методом - 28 (16,7 \%) пацієнтів. У 8 (4,7 \%) хворих спостерігали ремісію гострого холециститу, і вони були виписані під спостереження хірурга за місцем проживання. У 28 хворих, оперованих лапаротомічним доступом, холецистектомію і холедохолітотомію завершили зовнішнім дренажем холедоха у 23 (82,1 \%), холедоходуоденостомією - у 2 (7,1 \%), холедохоєюностомією ще у 3 $(10,7 \%)$ пацієнтів. Серед оперованих у 13 (46,4 \%) виявлено та дреновано паравезикальні абсцеси.

Наявність жовтяниці в момент госпіталізації та/або в анамнезі спостерігали у 20 (11,9 \%) хворих, у решти 147 (88,1 \%) пацієнтів прояви жовтяниці до або в період госпіталізації були відсутні. Аналіз характеру клінічних симптомів показав, що на біль у правій підреберній та епігастральній ділянці вказували 160 (95,8 \%) пацієнтів; підвищення температури тіла - 80 (47,9 \%), загальну слабість - 146 (87,4 \%) і лише у 4 (2,3 \%) пацієнтів спостерігали тріаду Шарко (жовтяниця, лихоманка, дрощі) (табл. 1). Отже, відсутність таких симптомів, як жовтяниця, лихоманка, свербіж шкіри, не виключають наявність конкрементів у жовчо-

Таблиця 1. Характер і частота клінічних симптомів при гострому калькульозному холециститі і малосимптомному холедохолітіазі

\begin{tabular}{||l|c||}
\hline \multicolumn{1}{||}{ Клінічний симптом } & Кількість \\
\hline Біль в епігастрію & $160(95,8 \%)$ \\
\hline Жовтяниця: & $20(11,9 \%)$ \\
\hline при госпіталізації & $12(7,1 \%)$ \\
\hline в анамнезі & $8(4,7 \%)$ \\
\hline Гіпертермія & $80(47,9 \%)$ \\
\hline Блювання & $28(16,7 \%)$ \\
\hline Свербіж шкіри & $17(10,1 \%)$ \\
\hline Загальна слабість & $146(87,4 \%)$ \\
\hline
\end{tabular}

вивідних шляхах і відповідно не можуть бути причиною відмови від подальшого пошуку можливої обструкції холедоха.

Аналіз лабораторних показників показав підвищення рівня білірубіну лише у 38 (22,7 \%) хворих, аланінамінотрасферази (АЛТ) у 82 (49,1 \%), аспартатамінотрансферази (АСТ) у 60 (35,9 \%), лужної фосфатази (ЛФ) у 131 (78,4 \%), гамаглютамілтранспептидази (ГГТП) у 139 (83,2 \%) пацієнтів (табл. 2). Найбільш інформативними в діагностиці холестазу є лужна фосфатаза та гамаглютамілтранспептидаза (від 78,4 до 83,2 \%). Підвищення хоча б одного показника спостерігали у 88,6 \% (не було підвищення у 19 пацієнтів). Вважаємо, що дані обстеження необхідно обов'язковий виконувати усім хворим із підозрою на холедохолітіаз.

Таблиця 2. Зміни біохімічних показників крові в пацієнтів із гострим холециститом та малосимптомним холедохолітіазом

\begin{tabular}{||l|c||}
\hline Показник, рівень якого підвищений & Кількість \\
\hline Білірубін & $38(22,7 \%)$ \\
\hline АЛТ & $82(49,1 \%)$ \\
\hline АСТ & $60(35,9 \%)$ \\
\hline ЛФ & $131(78,4 \%)$ \\
\hline ГГТП & $139(83,2 \%)$ \\
\hline \hline
\end{tabular}

За результатами УЗД, яке виконували усім пацієнтам, діаметр загальної жовчної протоки становив в середньому $(9,0 \pm 0,21)$ мм. Враховуючи тяжкість візуалізації позапечінкових жовчних проток, як правило, дослідження повторювали наступної після госпіталізації доби. Виділяють прямі та непрямі ехографічні ознаки холедохолітіазу. Прямими ознаками вважали наявність у просвіті загальної жовчної протоки ехогенного утвору з акустичною тінню, яку виявлено у 56 (33,5 \%) пацієнтів. До непрямих ознак відносили розширення внутрішньо- та позапечінкових проток, наявність в їх просвіті ехогенних структур без чіткої акустичної тіні - 59 (35,3 \%) пацієнтів. УЗД-ознаки холедохолітіазу не виявлено у 52 (31,1 \%) пацієнтів.

ЕРХПГ виконано 139 пацієнтам. Показаннями до її виконання були підозра за даними УЗД на малосимптомний холедохолітіаз, зміни в біохімічному аналізі крові (гіпербілірубінемія більше за рахунок прямої фракції, підвищення рівня ГГТП, ЛФ). Із 139 пацієнтів за допомогою ЕРХПГ діагностовано конкременти у 134 (96,4 \%) пацієнтів. У двох випадках отримано хибно негативний результат. Отже, чутливість методу склала 97,8 \%. У 23 (15,7 \%) пацієнтів ЕРХПГ виконувалась в ранньому післяопераційному періоді первинно, 
оскільки до ЛХЕ не були розпізнані клініко-лабораторні або ультрасонографічні ознаки малосимптомного холедохолітіазу.

Ускладнення після проведення лікувальної ЕРХПГ виникли у 5 (3,6 \%) пацієнтів: у двох хворих виникла кровотеча із папілотомного розрізу, яку вдалося зупинити консервативними методами, ще в трьох пацієнтів розвинувся гострий панкреатит. Усі пацієнти з приводу ускладнень проліковані консервативно.

МРХПГ виконувалась у 41 пацієнта із підозрою на холедохолітіаз; у 30 (73,2 \%) випадках було підтверджено холедохолітіаз, але після операції в одного хворого з невизначеними за результатами МРХПГ конкрементами в жовчних протоках (9,1 \% хибнонегативних результатів), перебіг післяопераційного періоду ускладнився розвитком механічної жовтяниці, з приводу чого виконано лікувальну ЕРХПГ та діагностовано мікрохоледохолітіаз і дрібні (2-4 мм) конкременти, які викликали запалення і обструкцію великого дуоденального сосочка. МРХПГ є неінвазивним методом обстеження, що дозволяє візуалізувати жовчні протоки та дає чітке розуміння співвідношення анатомічних структур у ділянці операції. Дане обстеження має особливу цінність для виявлення конкрементів малого розміру, а також, якщо неможливо, виконати ЕРХПГ.

Виникає проблема побудови оптимального діагностичного алгоритму, який, з одного боку, до-

\section{СПИСОК ЛІТЕРАТУРА}

1. Дооперационная диагностика скрытого холедохолитиаза / Т. Б. Ардасенов, Д. А. Фрейдович, А. Г. Паньков [и др.] // Анналы хирургической гепатологии. - 2011. - № 2. - С. 15-19. 2. Тактика лечения больных с бессимптомным холедохолитиазом / В. В. Грубник, А. И. Ткаченко, В. В. Ильяшенко, Б. В. Евсиков [и др.] // Український журнал хірургії. - 2013. № 3. - С. 74-79.

3. Шаповальянц С. Г. Проблемы современной диагностики холедохолитиаза / С. Г. Шаповальянц, Т. Б. Ардасенов, Д. А. Фрейдович // Российский журнал гастроэнтерологии, гепатологии, колопроктологии. - 2011. - № 2. - С. 22-29.

4. Современные аспекты диагностики и хирургического лечения холедохолитиаза (научний обзор) / Я. Г. Колкин, В. В. Хацко, С. В. Межаков [и др.] // Український журнал хірургії. - 2014. - № 2 (25). - С. 130-135.

5. Огородник П. В.Вибір методу ендоскопічного лікування хворих з приводу гострого холециститу, ускладненого холедохолітіазом / П. В. Огородник, В. І. Коломійцев, А. Г. Дейниченко // Клін. хірург. - 2014. - № 7. - С. 5-9.

6. Аналіз лікування хворих на калькульозний холецистит, ускладнений холедохолітіазом, у центрі лапараскопічної та зволяв би не використовувати без достатніх показань інвазивних і потенційно небезпечних методів обстеження (ЕРХПГ) у пацієнтів з малою ймовірністю діагностики холедохолітіазу, а, з іншого боку, не ускладнював діагностичний пошук у групі пацієнтів із високим (за клініко-лабораторними та ультрасонографічними даними) ризиком виявлення холедохолітіазу і використанням зайвих необгрунтованих діагностичних процедур, зокрема таких, як МРХПГ. Все це визначає необхідність подальших досліджень у цьому напрямку з метою опрацювання більш раціональних і об'єктивних систем діагностики холедохолітіазу при гострому калькульозному холециститі.

Висновки. Відсутність таких симптомів, як жовтяниця, лихоманка, свербіж шкіри не виключають наявність конкрементів в жовчовивідних шляхах і, відповідно, не можуть бути причиною для відмови у подальшому пошуку можливості обструкції холедоха.

Найбільш значимими із біохімічних показників холедохолітіазу є лужна фосфатаза та гамаглютамілтранспептидаза (78,4 \% і 83,2 \% відповідно). Підвищення хоча б одного з цих показників спостерігали у 88,6 \% пацієнтів.

ЕРХПГ і МРХПГ мають високу діагностичну цінністю у виявленні малосимптомних порушень прохідності жовчновивідних шляхів при гострому калькульозному холециститі.

малоінвазивної хірургії Вінницької обласної клінічної лікарні ім. М. І. Пирогова за 2013-2015 роки / В. В. Петрушенко, А. І. Ошовський, Я. В. Радьога, Н. А. Ляховченко // Вісник Вінницького національного медичного університету. 2016. - № 1. - С. 263-266.

7. Саволюк С. І. Діагностичний алгоритм у хворих із гострим калькульозним холециститом та підозрою на холедохолітіаз / С. І. Саволюк, Б. В. Свиридюк // Шпитальна хірургія. - 2016. - № 4. - С. 33-36.

8. Increased risk and severity of ERCP-related complicationsassociated with asymptomatic common bile duct stones / H. Saito, T. Kakuma, Y. Kadono, A. Urata, K. Kamikawa [et al.] // Endosc. Int. Open. - 2017. - Vol. 5, No. 9. - P. E809-E817.

9. Copelan A. Choledocholithiasis: Diagnosis and Management / A. Copelan, B. S. Kapoor // Tech. Vasc. Interv. Radiol. - 2015. Vol. 18, No. 4. - P. 244-255.

10. Natural course vs interventions to clear common bile duct stones: data from the Swedish Registry for Gallstone Surgery and Endoscopic Retrograde Cholangiopancreatography (GallRiks / M. Möller, U. Gustafsson, F. Rasmussen [et al.] // JAMA Surg. 2014. - Vol. 149, No. 10. - P. 1008-1013. 


\section{REFERENCES}

1. Ardasenov, T.B., Freydovich, D.A., Pankov, A.G., Budzinsky, S.A. \& Orlova, Ye.N. (2011). Dooperatsionnaya diagnostika skrytogo kholedokholitiaza [Preoperative diagnosis of latent choledocholithiasis]. Annaly khirurgicheskoy gepatologii - Annals of Surgical hepatology, 2, 15-19 [in Russian].

2. Grubnik, V.V., Tkachenko, A.I., Ilyashenko, V.V., Yevsikov, B.V. \& Vorotyntseva, K.O. (2013). Taktika lecheniya bolnykh s bessimptomnym kholedokholitiazom [Tactics of treatment of patients with asymptomatic choledocholithiasis]. Ukrainskyi zhurnal khirurhii - Ukrainian Journal of Surgery, 3, 74-79 [in Russian].

3. Shapovalyants, S.G., Ardasenov, T.B. \& Freydovich, D.A. (2011). Problemy sovremennoy diagnostiki kholedokholitiaza [Problems of modern diagnosis of choledocholithiasis]. Rossiyskiy zhurnal gastroenterologii, gepatologii, koloproktologii - Russian Journal of Gastroenterology, Hepatology, Coloproctology, 2, 2229 [in Russian].

4. Kolkin, Ya.G., Khatsko, V.V., Mezhakov, S.V., Borota, T.A. \& Chernyavskiy, A.R. (2014). Sovremennyye aspekty diagnostiki i khirurgicheskogo lecheniya kholedokholitiaza (nauchnyiy obzor) [Modern aspects of diagnosis and surgical treatment of choledocholithiasis (scientific review)]. Ukrainskyi zhurnal khirurhii - Ukrainian Journal of Surgery, 2 (25), 130-135 [in Russian].

5. Ohorodnik, P.V., Kolomiitsev, V.I. \& Deinichenko, A.H. (2014). Vybir metodu endoskopichnoho likuvannia khvorykh z pryvodu hostroho kholetsystytu, uskladnenoho kholedokholitiazom [Choice of the method of endoscopic treatment of patients with acute cholecystitis complicated by choledocholithiasis]. Klin. Khirurh. Clin. Surgery, 7, 5-9 [in Ukrainian].
6. Petrushenko, V.V., Oshovskyi, A.I., Radoha, Ya.V. \& Liakhovchenko, N.A. (2016). Analiz likuvannia khvorykh na kalkuloznyi kholetsystyt, uskladnenyi kholedokholitiazom, u tsentri laparaskopichnoi ta maloinvazyvnoi khirurhii Vinnytskoi oblasnoi klinichnoi likarni im. M. I. Pyrohova za 20132015 roky [Analysis of treatment of patients with calculous cholecystitis, complicated by choledocholithiasis, in the center of laparoscopic and non-invasive surgery of the M. Pyrohov Vinnytsia Regional Clinical Hospital for 2013-2015]. Visnyk Vinnytskoho natsionalnoho medychnoho universytetu - Bulletin of the Vinnytsia National Medical University, 1, 263-266 [in Ukrainian].

7. Savoliuk, S.I. \& Svyrydiuk, B.V. (2016). Diahnostychnyi alhorytm u khvorykh iz hostrym kalkuloznym kholetsystytom ta pidozroiu na kholedokholitiaz [Diagnostic algorithm in patients with acute calculous cholecystitis and suspicion of choledocholithiasis]. Shpytalna khirurhiia - Hospital Surgery, 4, 33-36 [in Ukrainian].

8. Saito, H., Kakuma, T., Kadono, Y., Urata, A., Kamikawa, K., Imamura, H., ... Tada, S. (2017). Increased risk and severity of ERCP-related complicationsassociated with asymptomatic common bile duct stones. Endosc. Int. Open, 5, 9, E809-E817.

9. Copelan, A. \& Kapoor, B.S. (2015). Choledocholithiasis: Diagnosis and management. Tech. Vasc. Interv. Radiol., 18, 4, 244-255.

10. Möller, M., Gustafsson, U., Rasmussen, F., Persson, G. \& Thorell, A. (2014). Natural course vs interventions to clear common bile duct stones: data from the Swedish Registry for Gallstone Surgery and Endoscopic Retrograde Cholangiopancreatography (GallRiks). JAMA Surg., 149, 10, 1008-1013.

Отримано 12.02.2018

\title{
O. M. TERLETSKIY, V. I. KOLOMIYTSEV
}

Danylo Halytskyi Lviv National Medical University

\section{THE PROBLEM OF DIAGNOSTICS OF SMALL SYMPTOMATIC CHOLEDOCHOLITHIASIS IN PATIENTS WITH ACUTE CALCULUS CHOLECYSTITIS}

\begin{abstract}
The aim of the work: to improve the results of the diagnosis of small symptomatic choledocholithiasis.
Materials and Methods. Diagnosis and treatment of 167 patients with acute calculous cholecystitis and suspicion of choledocholithiasis in the period from 2007 to 2016 were analyzed.

Results and Discussion. In patients with acute calculous cholecystitis and small symptomatic choledocholithiasis, the pain in the right hypochondrium and epigastric areas (95.8\%), body temperature (47.9\%), and general weakness (87.4 \%) and only in 4 (2.3 \%) of patients watched the Sharko triad (jaundice, fever, chills). In the analysis of biochemical parameters of blood, we observed an increase in the level of bilirubin in only 38 (22.7 \%) patients, and alkaline phosphatase in 131 (78.4 \%) and gama-glutamyl transpeptidase in 139 (83.2 \%) patients. According to the results of ultrasound signs of choledocholithiasis isolated in $68.8 \%$ of patients; the diameter of the total bile duct was on average $(9.0 \pm 0.21) \mathrm{mm}$. There were not ultrasound signs of hypertension or other biliary pathology in 52 (31.1\%) patients. Among 41 patients with MRCP, choledocholithiasis was diagnosed in 30 (73.2 \%) patients. During ERCP, concrements were found in $97.8 \%$ of patients. Complications after the treatment of ERCP occurred in 5 (3.6 \%) patients.
\end{abstract}

Key words: small symptomatic choledocholithiasis; ultrasonography; endoscopic retrograde cholangiopancreatography; magnetic resonance cholangiopancreatography. 
Львовский национальный медицинский университет имени Данила Галицкого

\section{ПРОБЛЕМА ДИАГНОСТИКИ МАЛОСИМПТОМНОГО ХОЛЕДОХОЛИТИАЗА У ПАЦИЕНТОВ С ОСТРЫМ КАЛЬКУЛЕЗНЫМ ХОЛЕЦИСТИТОМ}

Цель работи: улучшить результаты диагностики малосимптомного холедохолитиаза.

Материалы и методы. Проведен анализ диагностики и лечения 167 пациентов с острым калькулезным холециститом и подозрением на холедохолитиаз в период с 2007 по 2016 г.

Результаты исследований и их обсуждение. Пациенты с острым калькулезным холециститом и малосимптомным холедохолитиазом чаще всего жаловались на боль в правом подреберном и эпигастральном участках (95,8 \%), повышение температуры тела $(47,9$ \%) и общую слабость $(87,4$ \%) и только в 4 (2,3 \%) пациентов наблюдали триаду Шарко (желтуха, лихорадка, дрощи). При анализе биохимических показателей крови отмечено повышение уровня билирубина только у 38 (22,7 \%) пациентов, а щелочной фосфатазы в 131 (78,4 \%) и гамаглютамилтранспептидазы в 139 (83,2 \%) пациентов. По результатам УЗИ подозрение на холедохолитиаз возникло в 68,8 \% пациентов; диаметр общего желчного протока составил в среднем $(9,0 \pm 0,21)$ мм. Не выявлено УЗИ-признаков гипертензии или другой билиарной проточной патологии у 52 (31,1 \%) пациентов. Среди 41 пациента с помощью МРХПГ диагностирован холедохолитиаз у 30 (73,2 \%) больных. Во время ЭРХПГ обнаружено конкременты в 97,8 \% пациентов. Осложнения после проведения лечебной ЭРХПГ возникли у 5 (3,6 \%) пациентов.

Ключевые слова: малосимптомный холедохолитиаз; ультрасонография; эндоскопическая ретроградная холангиопанкреатикография; магнитно-резонансная холангиопанкреатикография. 